\title{
PROBLEMATIKA ISBAT NIKAH DALAM OPTIK PERUNDANG-UNDANGAN
}

\author{
Wahidullah', Ricky Khoirul Umam² \\ 1Universitas Islam Nahdlatul Ulama Jepara \\ e-mail: wahidullah@unisnu.ac.id \\ 2 Universitas Islam Nahdlatul Ulama Jepara \\ e-mail: rickykhoirulumam@gmail.com
}

\begin{abstract}
The marriage certificate is the process of recording marriage to a marriage that is carried out on a legal basis and has not been approved by the legality or marriage certificate of the marriage. The purpose of the marriage ratification is to obtain legal certainty that is appropriate to the marriage that has been done, namely by registering a marriage and obtaining a marriage certificate to facilitate the civil process in the family. This type of research is qualitative by discussing sociology and it was carried out using inductive analytical methods by discussing the issue of the implementation of marriage rights in the field and the implications of marriage rights to the status of marital power in terms of the system of agreement-invitation legislation. The results of this study are the implementation of the marriage certificate in the Jepara Religious Court has been carried out according to procedures that have been received and carried out by the Jepara Religious Court in accordance with the provisions of the procedural law of the religion in accordance with statutory provisions regulated by Law Number 50 Year 2009 concerning the Religious Courts.
\end{abstract}

Kata kunci: itsbat pernikahan, registrasi pernikahan, kekuatan hukum.

\section{PENDAHULUAN}

Pencatatan perkawinan merupakan hak dasar bagi pasangan suami istri dalam melangsungkan sebuah perkawinan. Hak dasar pencatatan perkawinan tersebut menjadi suatu bentuk upaya reformasi hukum keluarga guna mengupayakan penertiban perkawinan dalam masyarakat, menjaga kesucian suatu perkawinan, dan merupakan bentuk upaya perlindungan bagi pihak istri maupun anak dalam dalam rumah tangga untuk memperoleh hak-hak keluarga yang timbul akibat adanya perkawinan seperti hak waris dan lain-lain (Faizah, 2014: 1). Permohonan Isbat Nikah dilakukan juga dikarenakan perkawinan yang terjadi setelah adanya
Undang-undang perkawinan mengandung prinsip pencatatan perkawinan demi menjaga kemaslahatan keluarga. (Mahmud, 2014: 71)

Pada dasarnya pencatatan perkawinan tidak diatur di dalam nash, baik Al-Qur'an mapun Sunnah terkait perintah pencatatan nikah. Namun, seiring berkembangnya suatu kehidupan, serta reformasi hukum keluarga dalam hal perkawinan dari masa dahulu sampai sekarang, keberadaan alat bukti otentik terhadap sebuah perkawinan menjadi sebuah kebutuhan yang harus dilakukan dan dimiliki dalam status perkawinan yang dilangsungkan.

Bertitik dari hal tersebut, pencatatan perkawinan sebagai bentuk keharusan 
dan merupakan bentuk aturan yang tertera dalam Pasal 2 ayat 2 UndangUndang Perkawinan. Pencatatan perkawinan dilakukan berdasarkan peraturan yang telah diatur dalam perundang-undangan dan merupakan bentuk upaya dalam reformasi hukum kelurga Islam untuk menertibkan perkawinan, dan juga untuk melindungi hak-hak perkawinan antara suami dan istri apabila pada suatu hari nanti terjadi pesengketaan dalam suatu perkawinan tersebut.

Karena untuk dapat membuktikan sebuah perkawinan yang sah adalah harus dengan adanya akta nikah, untuk memperoleh kejelasan status hukum agar dapat meminimalisir terjadinya persengketaaan. Pencatatan perkawinan merupakan bentuk kebijakan yang dilakukan pemerintah dalam melindungi serta terjaminnya hak sebagai pasangan suami istri, serta buah perkawinan itu sendiri.

Permasalahan yang terjadi apabila pasangan suami istri tidak dicatatkan perkawinannya dan tidak mempunyai sebuah bukti akta nikah, akan menimbulkan berbagai permasalahan dikemudian hari seperti halnya tidak bisa mengurus akta kelahiran anak yang imbasnya akan menghilangkan hak atas anak baik dalam hak kewarisan, pendidikan dan hak-hak lainnya. Mengacu pada penjelasan umum angka 4 Undang-Undang Perkawinan, perkawinan sah adalah perkawinan yang dilakukan sesuai agamanya dan kepercayaannya. Disatu sisi terdapat ketentuan yang mengatur dimana dalam perkawinan harus dicatat sesuai peraturan dalam perundangundangan. Aturan pencatatan tersebut memiliki korelasi dengan aturan pencatatan mengenai kelahiran anak, peristiwa kematian dan lain sebagainya. Fungsi dan kedudukan pencatatan perkawinan dalam hal ini untuk menjamin hak dasar untuk memperoleh sebuah bukti kepastian hukum, serta memperoleh kemudahan hukum, selain hanya sebagai satu alat bukti atau akta otentik telah terjadi suatu perkawinan. (Djubaidah, 2012: 215)

Fenomena yang kerap terjadi dan dijumpai di masyarakat adalah perkawinan di bawah tangan, atau bisa dibilang perkawinan yang dilakukan hanya atas dasar pilihan hukum yang dilakukan berdasarkan pada hukum agama Islam dengan terpenuhinya syarat dan rukun perkawinan dalam agama Islam dan hal tersebut hanya memenuhi ketentuan Pasal 2 ayat (1) UndangUndang Perkawinan, namun pasal aturan tersebut tidak memenuhi ketentuan dalam Pasal 2 ayat (2) yang dimana menyatakan bahwasanya suatu perkawinan sudah sepatutnya melaporkan atau mencatatkan perkawinan pada Kantor Urusan Agama. Karena perkawinan di bawah tangan yang dilakukan atas dasar Undang-Undang dianggap hanya melanggar adminstrasi dan hukum perkawinan di Indonesia. Namun secara syarat dan rukun agama perkawainan tersebut tetap sah. Untuk itu mereka yang menikah di bawah tangan mengajukan sidang isbat untuk melegalkan perkawinan mereka seperti yang terjadi pada beberapa tempat lembaga Pengadilan Agama di SulawesiSelatan yaitu Makassar, Sungguminasa, Takalar, dan Watampone. (Mukhtaruddin, 2013: 228)

Berkaca dari fenomena yang terdapat dimasyarakat tersebut, dapat digambarkan secara jelas data yang 
diperoleh dari Pengadilan Agama Jepara memaparkan sepanjang tahun 2017 telah menerima perkara masuk mengenai pengesahan perkawinan/itsbat nikah 23 pasangan suami istri.

Pengadilan Agama dalam hal ini sebagai pemangku kebijakan hukum yang berwenang untuk memutuskan suatu perkara hukum mengenai Itsbat Nikah bagaimana Pengadilan Agama Jepara dalam memproses suatu perkara Itsbat Nikah dan sudah menjadi kewenangan dari Pengadilan Agama ini untuk memproses itsbat nikah demi suatu status perkawinan serta demi tertibnya dan tercatatnya suatu perkawinan yang telah dilaksanakan.

Ambiguitas mengenai kewenangan dan juga kepastian hukum terkait pencatatan perkawinan membuat masyarakat jenuh serta bimbang dengan aturan, tetapi ada pula yang mejadikan suatu aturan atau kewenangan tidak berjalan secara efektif. Bahwa dalam Undang-Undang Perkawinan terdapat sebuah asas legalitas yang mengacu pada dua arah yang berbeda sebagai dasar melakukan sebuah perkawinan yaitu adalah dasar suatu keabsahan sebuah perkawinan dan syarat telah terjadi sebuah perkawinan. Hal ini tidak lazim dalam menentukan korelasi hukum dan bahkan merupakan sumber kegaduhan terkait perkawinan yang tercatat dan belum tercatat bahkan tidak dicatatkan atau karena tidak terpenuhinya syarat lain, karena dalam setiap korelasi hukum yang dilakukan sesuai syarat hukum akan menjadikan serta melahirkan sebuah hubungan hukum dan akibat hukum yang sah untuk sebuah perkawinan. (Kharlie, 2013: 191)
Sebagai akibat penafsiran atau penjelasan mengenai Undang-Undang Nomor 1 Tahun 1974 mengenai pencatatan perkawinan hanya bersifat administratif belaka jadi tidak menyebabkan batalnya perkawinan, berhubung dengan perihal tersebut disinyalir sekarang baik dalam berita di media masa serta sengketa yang dibawa ke Pengadilan Agama dan juga Pengadilan Negeri serta menurut pendapat umum bahwa perkawinan yang dilakukan di bawah tangan adalah sah. Perkawinan tersebut maksudnya ialah bahwa perkawinan tetap dilakukan dengan berlandaskan agama Islam dan rukun-rukun ataupun syarat-syarat yang telah menjadi ketentuan dalam agama Islam, hanya saja pelaksanaannya yang tidak dilakukan melalui pendaftaran serta pencatatan di Kantor Urusan Agama yang berada di wilayah tempat tinggal. Menurut istilah dari beberapa hakim di Pengadilan Agama menyatakan: perkawinan di bawah tangan atau perkawinan liar tersebut oleh sebagian ulama atau umat besar Islam tetap sah secara hukum agama, meskipun tidak mendaftarkan dan dicatatkan pada Kantor Urusan Agama Setempat. Untuk itu Pengadilan Agama dalam menjernihkan perkara pengesahan nikah, maka Hakim dalam pertimbangan hukumnya dalam memutus perkara mendasarkan pada Kompilasi Hukum Islam Pasal 7 ayat 3 dengan tidak mengabaikan tiga unsur yang harus terpenuhi dalam penegakan hukum yaitu kepastian hukum (Rechtssicherheit), kemanfaatan (Zweckmassigkeit) dan keadilan (Gerechtigkeit). (Yakin, 2015: 254)

Ini merupakan masalah kecil tapi sangat berdampak besar terhadap akibat hukum dari perkawinan tersebut, terutama 
menyangkut dengan pembuktian nasab (hubungan darah atau keturunan) masalah harta bersama dalam keluarga antara suami dan istri, hak waris serta hak saling mewarisi antara anak dan orang tua, demikian juga akan berdampak bagi keberlangsungan keluarga tersebut. Akan bertambah kusut lagi apabila perkawinan di bawah tangan tersebut dilakukan untuk beristri lebih dari satu atau bisa dibilang perkawinan kedua, ketiga, dan juga seterusnya. (Ramulyo, 2006: 71)

Berdasarkan uraian di atas, sudah semestinya untuk dibahas pelaksanaan Itsbat Nikah di Pengadilan Agama Jepara dalam tinjauan sistem perundangundangan peradilan mengenai aturan serta prosedur Itsbat Nikah yang dilakukan di Pengadilan Agama Jepara menurut perundang-undangan di Indonesia, Kendala-kendala yang dihadapi dalam melakukan Itsbat Nikah dan implikasinya terhadap status perkawinan.

\section{METODE PENELITIAN}

Jenis penelitian ini adalah penelitian kualitatif, peneliti mendeskripsikan mengenai data yang diperoleh baik dari bentuk tertulis atau lisan yang bersumber dari subjek penelitian. Penelitian kualitatif ini disajikan secara langsung korelasi antara responden dengan peneliti.

Metode pendekatan dalam peneltian ini adalah bersifat sosiologis. Pendekatan ini dimaksudkan dalam mempelajari secara mendalam mengenai kondisi suatu interaksi sosial, maupun masyarakat, Penelitian mendalam dalam hubungan sosial yang menghasilkan gambaran yang lengkap serta memiliki ruang lingkup yang cakupannya keseluruhan kehidupan dan mencakup keseluruhan faktor dan kejadian.

Dalam penelitian sosiologis ini, maka data yang diteliti pada awalnya data sekunder, kemudian meneliti terkait data primer di lapangan yaitu masyarakat yang dijadikan bahan utama dalam penelitian. (Soekanto, 2015: 52) Penelitian hukum sosiologis hakikatnya adalah bentuk penelitian terhadap identifikasi hukum dari dan sebagai gejala sosial serta menganilisis hubungan hukum dengan gejala sosial lainnya, yang menjadi pokok bahasan dalam penelitian hukum sosiologis adalah efektifitas hukum, studi dampak hukum, studi lembaga-lembaga hukum, dan identifikasi hukum dalam masyarakat. (Amir Mu'allim, 2001: 97)

\section{HASIL DAN PEMBAHASAN}

\section{Pelaksanaan Itsbat Nikah Di Pengadilan Agama Jepara}

Pengadilan Agama Jepara memiliki wewenang terkait permasalahan perkawinan, yang menjadi salah satu kewenangan dari Pengadilan Agama Jepara adalah Itsbat Nikah. Itsbat nikah tersebut masih merupakan ranah dari kompetensi Pengadilan Agama Jepara sebagaimana diatur dalam ketentuan Pasal 49 ayat 2 Undang-Undang Nomor 7 Tahun 1989

Sebagaimana penjelasan dalam Kompilasi Hukum Islam, suatu perbuatan hukum dalam hal ini adalah perkawinan bisa dikatakan sah apabila dilakukan sesuai ketetapan dalam Hukum Islam dan juga tidak menyimpang dari UndangUndang Perkawinan. Itsbat Nikah dalam pengaturannya menurut perundangundangan Indonesia, diartikan sebagai bentuk upaya seseorang dalam menetapkan atau melegalkan perkawinannya melalui pencatatan 
serta prosedur yang berlaku dalam lingkup peradilan Indonesia guna mendapatkan pengesahan hukum sebagaimana dalam penjelasan Putusan Mahkamah Agung RI KMA/032/SK/2006 yang menjelaskan mengenai pelaksanaan tugas dan administrasi pengadilan, diatur dengan pedoman bahwa Itsbat Nikah adalah penetapan dari perkawinan yang dilakukan atas dasar syariat Islam, namun dalam perkawinan tersebut belum atau tidak tercatatkan di Kantor Urusan Agama atau Pegawai Pencatat yang berwenang. Perkawinan yang sedemikan tersebut adalah perkawinan yang tidak dicatatkan lebih dikenal dengan perkawian di bawah tangan. Itsbat Nikah ini pada umumnya diajukan oleh para pihak yang berperkara yang belum memiliki akta nikah karena perkawinan yang para pihak lakukan dulunya belum dicatatkan atau belum tercatatkan yang pada suatu waktu ketika akan menumbuhkan sebuah masalah baru, karena tidak memperoleh akta nikah atau buku nikah ini imbasnya adalah segala perbuatan yang menjadi suatu akibat dari perkawinan itu tidak dapat terpenuhi di antaranya adalah dalam perihal kepastian status hukum perkawinan namun pada umumnya adalah untuk melengkapi syarat pada administrasi perkawinan dan juga dalam hal pengurusan surat keterangan pensiunan, pengurusan pembuatan paspor, pengurusan akta kelahiran anak, harta bersama dan lain sebagainya.

Dapat dilihat dari fungsi dengan penetapan Itsbat Nikah tersebut sangan berkaitan dalam hal keperdataan yang merupakan bukti otentik telah terjadinya perkawinan serta menjadi pelindung atau payung hukum dalam pengurusan perkara sengketa keperdataan serta mendapat pengakuan hukum terkait perkawinan yang telah dilakukan tersebut. Isbat Nikah di beberapa tempat mengalami kenaikan yang fantatstis seperti yang terjadi di pandeglang, isbat pada tahun 2013 sejumlah 68 perkara pada tahun 2014 menjadi 135 perkara. (Ahmad, 2016: 120)

Mengenai prosedur dalam pelaksanaan itsbat nikah di Pengadilan Agama Jepara, berdasarkan data penelitian di lapangan dalam prosedur pelaksanaannya tidak jauh berbeda dengan pengajuan prosedur perkara keperdataan perkawinan lainnya. Tentu dalam perkara perdata Itsbat Nikah ini terdapat perbedaan di antaranya yaitu mengenai tujuan perkara diajukan, pihak yang mengajukan dan juga persyaratan dalam mengajukan pengesahan perkawinan atau Itsbat Nikah ke Pengadilan Agama Jepara.

Dalam pengajuannya para pihak dituntut untuk dapat memberikan keterangan bahwa sebanyak perihal perkawinan yang dilakukan, baik dari para wali yang hadir dalam perkawinan tersebut, para saksi yang adalah perkara perdata perkawinan pemohon tersebut. Masyarakat rata-rata mengetahui pelaksanaan/prosedur Itsbat Nikah di Pengadilan Agama Jepara. Ditunjukan dengan jumlah data presentase dari sampel yang melakukan pengisian kuisioner ada $71,4 \%$ mengetahui sebanyak $28,6 \%$ menjawab tidak mengetahui prosedur Itsbat Nikah di Pengadilan Agama.

Terkait prosedur pengajuan Itsbat Nikah, dalam pengajuannya memiliki dua cara yaitu adalah voluntair dan kontensius. 
Adapun yang dimaksud dengan voluntair disini apabila suami dan istri dalam hal ini bersama-sama ingin mengajukan permohonannya ke Pengadilan Agama Jepara karena perkawinan sirri yang telah dilakukan sebelumnya. Karena berbentuk permohonan maka dalam hal ini nantinya produk hukum dari pengesahan perkawinan ini adalah sebuah penetapan atau pengesahan perkawinan terhadap pasangan suami tersebut. Justru apabila hanya salah satu pihak yang berkenang untuk mengajukan pengesahan perkawinan tersebut maka tidak bisa dikatakan perkara voluntair (permohonan) maka akan berbentuk kontensius (gugatan).

Status pemohon akan diperoleh oleh pihak yang mengajukan sedangkan status termohon akan diperoleh oleh pihak yang tidak ingin mengajukan pengesahan perkawinan tersebut di Pengadilan Agama Jepara. dan produk hukum apabila suatu pengajuan perkara pengesahan perkawinan tersebut berbentuk gugatan (kontensius) adalah sebuah putusan. Perkara gugatan. tersebut juga bisa dimasukan apabila pemohon mengajukan perkara terhadap perkawinan poligami dan juga status anak, atau pihak lain yang memiliki kepentingan hukum dalam terjadinya perkawinan tersebut.

Pihak yang bisa mengajukan pengesahan perkawinan maka dapat mengacu pada ketentuan Kompilasi Hukum Islam pada Pasal 7 ayat 4 adapun pihak yang dimaksud adalah suami, istri, anak dan orang tua atau wali nikah (yang berkepentingan terhadap perkawinan tersebut). Para pihak tersebut tentunya harus melampirkan atau memenuhi persyaratan baik berupa dokumen atau surat serta para pihak, sebelum pengajuan permohonan Itsbat Nikah di antaranya adalah melampirkan surat permohoan 5 rangkap apabila pengajuan perkara tersebur berbentuk voluntair. Jika contensius ditambahkan termohon, fotocopy KTP Suami, istri/pemohon, fotocopy kartu keluarga, Surat Keterangan dari desa tentang suami dan istri waktu menikah (asli), Surat Keterangan dari Kantor Urusan Agama (Asli) tentang tidak tercatatnya pernikahan pada register nikah di KUA dan membayar panjar perkara (Pasal 121 Ayat 4 Herzien Inlandsch Reglement [HIR]). Dalam keperdaataan Pengadilan Agama Jepara sepanjang tahun 2017 Terdapat 23 Permohonan Pengesahan Perkawinan/Itsbat Nikah.

Berdasarkan data dalam penelitian yang dilakukan dilapangan mengenai prosedur pengajuan Itsbat Nikah dilingkup Pengadilan Agama Jepara adalah dengan diketahui bahwa faktor yang melatarbelakangi mengenai para pihak mengajukan permohonan pengesahan perkawinan ke Pengadilan Agama Jepara adalah karena perkawinan yang para pihak ajukan belum tercatatkan atau belum mencatatkan perkawinannya ke Kantor Urusan Agama. Selanjutnya karena pernikahan yang dilakukan dahulu sebelum berlakunya UndangUndang Perkawinan, pengurusan pensiunan maupun pengurusan paspor untuk keberangkatan haji, pengurusan akta kelahiran anak, pengurusan sengketa harta bersama dan warisan dari perkawinan tersebut.

Pengadilan agama dalam melakukan pemeriksaan perkara selalu mengedapankan asas fleksibilitas sebagaiamana tercantum dalam ketentuan Pasal 57 (3) Undang-Undang Nomor 7 Tahun 1989 Peradilan Agama dalam hal ini adalah Pengadilan Agama 
Jepara melakukan pemeriksanan perkara secara cepat dan biaya ringan serta membantu bagi kedua pihak yang berperkara tersebut guna menghadapi masalah atau hambatan yang dialami oleh pihak yang mengajukan secara sederhana, cepat dan fleksibel.

Dari pemaparan analisis di atas dapat dikatakan bahwa dalam prosedur pengajuan perkara dalam hal ini adalah pengajuan perkara itsbat nikah di Pengadilan Agama Jepara dan berdasarkan analisis data serta penggalian data yang dilakukan selama masa penelitian berlangsung dapat diambil kebenaran bahwa dalam keseluruhan prosedur yang sudah diterima dan dijalankan oleh Pengadilan Agama Jepara telah sesuai dengan ketentuan hukum acara Peradilan Agama yang berlaku sebagaimana diatur dalam ketentuan HIR dan perturan perundang-undang yang berlaku serta tingkat ketahuan masyarakat terkait pelaskanaan itsbat nikah digambarkan dalam presentase sebesar 71,4\% dari populasi data tabel kuisoner memahami terkait bagaimana pelaksanaan dan sisanya tidak mengetahui terkait prosedur pelaksanaan Itsbat Nikah.

\section{Kendala-Kendala Yang Dihadapi Pengadilan Agama Jepara dan Masyarakat dalam Penetapan Terhadap Itsbat Nikah}

Dalam menerima perkara perkait perbuatan hukum dalam hal ini adalah pengesahan perkawinan tentu dalam hal tersebut terdapat kendala atau hambatan yang dapat mengganggu proses jalannya permohonan tersebur dan dapat mengakibatkan permohonan tersebut tidak dapat terkabulkan sesuai dengan kehendak pihak yang berperkara.

Pengadilan Agama sebagai pemangku kebijakan yang berwenang dalam menerima, memeriksa dan memutuskan perkara tentu dalam setiap proses persidangan yang dijalankan tidak ingin memperlambat atau mempersulit pihak untuk memproses permohonnya. Selama proses permohonan tersebut asalkan dari pihak yang berperkara dapat mengikuti prosedur dari Pengadilan serta mengikuti proses pengajuan sampai perlengkapan syarat administrasi dan syarat dokumentasi yang menjadi bahan pokok dalam setiap perkara yang diajukan.

Karena kendala tersebut timbul bukan dari pihak pengadilan yang lalai atau lama dari selama proses pengadilan itu berlangsung. Melainkan justru disebabkan akibat dari pihak pemohon yang belum atau tidak bisa memenuhi prosedur dan ketentuan serta syarat selama persidangan berlangsung di Pengadilan Agama Jepara. karena hal tersebut dapat menjadikan suatu permohonan tersebut dapat diterima ataupun ditolak karena kurangnya perlengkapan persyaratan administrasi yang menjadi bahan pokok dalam setiap proses persidangan pengesahan pekawinan yang akan berlangsung

Apabila dalam setiap perkara perdata yang diajukan disertai dengan pemenuhan ketentuan dan syarat selama dalam proses pengajuan permohonan sampai penetapan itu terpenuhi dengan baik sesuai dengan ketetapan perundangperundangan dan perbuatan hukum dalam hal ini adalah perkawinan yang dilakukan sesuai denga syarat dan rukum 
hukum Islam sebagaimana yang menjadi ketentuan dapat diterimanya perkara tersebut dan selama proses pengajuan dapat dilakukan tepat waktu maka dalam setiap proses permohonan itu berlangsung akan dapat cepat terselesaikan.

Berdasarkan hasil penelurusan penelitian mengenai kendala-kendala Pengadilan Agama Jepara dalam penetapan Itsbat Nikah antara lain adalah kendala dari pihak pemohon yakni pasangan suami istri tidak dapat hadir waktu persidangan serta kurangnya saksi dan tidak adanya kesesuain saksi dengan perkara atau bisa dikatakan membawa saksi yang meragukan. Perkawinan yang dilakukan merupakan perkawinan yang terjadi sebelum di sahkannya UndangUndang Perkawinan yaitu UndangUndang No 1 Tahun 1974. Terhambat oleh saksi perkawinan yang menyaksikan kejadian perkawinan tersebut. Faktor biaya yang masih kurang dapat terpenuhi, khususnya bagi masyarakat yang belum mampu terkait pengajuan permohonan pengesahan itsbat nikah tersebut dan juga sebagian masyarakat masih banyak yang belum mengerti tentang adanya bantuan bagi mereka atau pihak yang berperkara tapi tidak mampu untuk berperkara.

Dan juga faktor ketidaktahuan dan kepedulian masyarakat terdahulu dalam mencatatkan perkawinannya sehingga kendala justru datang dari pihak masyarakat yang tidak mencatatkan perkawinannya karena terkendala dalam hal kurangnya sosialisasi terkait pentingnya memiliki akta nikah, kurangnya pengetahuan mengenai persyaratan yang diajukan, terkendala masalah jarak yang jauh, dan juga kendala dalam proses serta pembiayaan.
Sebagaimana pemaparan analisis mengenai kendala diatas dalam konsep substansinya dari Pengadilan Agama bahwa kendala rata-rata dalampelaksanaan Itsbat Nikah hadir dari pihak beperkara yang belum memenuhi prosedur maupun persyaratan selama persidangan diadakan. Sedangkan dari data menunjukkan pihak masyarakat berdasarkan analisis serta data dalam tabel kuisoner sebanyak $71,4 \%$ dari jumlah populasi responden menyatakan bahwa masyarakat tahu mengenai pelaksanaan/prosedur Itsbat Nikah, serta sebanyak $57,1 \%$ yang memahami terkait persyaratan yang menjadi ketentuan. Kendala lainnya adalah dari jarak dengan ditunjukan presentase 85,7\% yang menjawab ya sedangkan presentase $14,3 \%$ menjawab tidak, terkait permasalahan dalam pembiayaan juga menjadi suatu kendala yang mendasar yang dihadapi masyarakat ditunjukan dengan $71,4 \%$ dalam kendala-kendala yang dihadapi masyarakat dalam melaksanakan itsbat/pengesahan perkawinan di Jepara.

Maka kemudian dapat dipahami untuk tercapainya kemaslahatan serta menjawab dari kendala tersebut adalah Pengadilan Agama dalam memproses perkara yang sederhana, cepat dan biaya ringan serta fleksibel. Sebagaimana tertera dalam ketentuan Pasal 2 Ayat 4 UndangUndang No. 48 Tahun 2009 tentang kekuasaan kehakiman. Dalam membantu serta berusaha menjelaskan dan mengatasi segala kendala pemohon dalam perkara atau para pihak. Serta dalam penjelasan terkait penyelesaian dalam kendala tersebut harus disampaikan dengan mudah secara jelas serta mudah dipahami oleh para pihak dalam pelaksanaan setiap perkara yang dijalani. Bahwa dalam gambaran data bagi 
masyarakat $71,4 \%$ yang terkendala dalam faktor pembiayaan, sehingga dapat diberikan kemudahan yaitu dengan diadakannya berperkara melalui prodeo artinya putusan yang dalam hal tersebut dapat berperkara ditanggung oleh negara melalui ketentuan menjadi masyarakat dapat terbantu sebagaimana dalam ketentuan PERMA No 1 Tahun 2014. Dalam ketentuan tersebut mengatur mengenai kriteria yang dapat memperoleh pembebasan biaya bagi masyarakat yang terkendala dalam pembiayaan perkara dengan menyertakan surat keterangan.

Kendala karena jarak dari data angka memaparkan angka 87,3\% tersebut, untuk itu bisa kemudian diambil solusi Pengadilan harus hadir mengadakan persidangan keliling di daerah agar masyarakat dapat memperoleh keadilan dan kepastian hukum serta masyarakat lebih mudah dalam mengakses Pengadilan. Masyarakat juga tidak kesulitan dalam hal biaya untuk menjangkau wilayah yang relatif jauh dari beberapa kecamatan yang ada, sedangkan terkait hambatan dalam kurangnya sosialisasi terkait pentingnya pencatatan perkawinan bagi masyarakat. Pemberian informasi serta pemahaman yang akurat dari pengadilan kepada masyarakat secara baik masyarakat tentu akan dapat memahami mengenai kepentingan pencatatan tersebut, karena informasi dan sosialisasi merupakan faktor yang penting untuk mengakses keadilan ke pengadilan.

\section{Implikasi Penegakan Itsbat Nikah Terhadap Kekuatan Hukum Status Perkawinan Ditinjau dari Perundang- Undangan di Indonesia}

Perkawinan dianggap sah apabila dilakukan sesuai dengan rukun dan syarat sebagaimana yang menjadi ketentuan dalam hukum agama Islam dan juga ditekankan dengan ketentuan dalam Pasal 2 ayat 1 Undang-Undang. Perkawinan. dalam hal perkawinan yang tidak dapat membuktikan dengan menunjukan bukti keabsahan atas perkawinan tersebut yaitu berupa buku atau akta nikah yang merupakan bukti otentik telah terjadinya perkawinan maka dapat diajukan Itsbat Nikahnya ke Pengadilan Agama Jepara.

Sebagaimana dalam diatur dalam Kompilasi Hukum Islam Pasal 7 ayat 2 dan 3 menjelaskan mengenai kewenangan Itsbat Nikah. Pada ayat 2 tersebut menyatakan dalam perkawinan tidak dapat membuktikan dengan adanya bukti otentik atau akta nikah dari perkawinan tersebut maka dapat diajukan Itsbat Nikahnya ke Pengadilan Agama Jepara. Dalam pelaksanaannya perkawinan harus ditetapkan oleh hukum, karena otoritas dari pengadilan tidak akan berjalan jika tidak ada hukum yang mengaturnya. Namun dipandang dari segi yuridis, jika menelisik lebih dalam mengenai ketentuan dalam Pasal 7 ayat 2 Kompilasi Hukum Islam tersebut jika berfikir secara seksama, aturan Undang-Undang tersebut mengatur mengenai kompetensi absolut terkait Itsbat Nikah tanpa pembatasan dan pasal tersebut diberlakukan untuk perkawinan di bawah tangan yang terjadi sebelum berlakunya Undang-Undang Perkawinan. Namun dalam aspek sosiologis justru dapat membuat peluang terkait perkawinan di bawah tangan secara luas jika perkawinan di bawah tersebut dilakukan setelah berlakunya 
Undang-Undang perkawinan dan diberi tempat untuk Itsbat Nikah.

Menelisik dalam ketentuan Pasal 7 ayat 3 Kompilasi Hukum Islam, adanya perkawinan dalam rangka penyelesaian perceraian. Dalam aturan tersebut tidak ada kejelasan terkait perkawinan yang dilakukan setelah atau sebelum UndangUndang Perkawinan tersebut diberlakukan, dan perlu adanya batasan kewenangan dalam aturan ini, karena data di lapangan mencuatkan bahwa alasan pengajuan Istbat Nikah ini bukan sekedar untuk pengeurusan perceraian melainkan dengan hal/alasan yang lain mengapa sampai harus diistbatkan. Perihal oleh hilangnya buku nikah/akta nikah bukan menjadi masalah dan sudah menjadi keharusan dalam kewenangan Kantor Urusan Agama menyimpan data dari pihak yang berperkara atau yang bersangkutan tersebut.

Mengenai keraguan terkait perkawinan yang dilakukan dalam hal menentukan sah dan tidaknya salah satu syarat dalam perkawinan tersebut justru dianggap tidak benar karena pihak yang menikah di bawah tangan dahulu itu melakukan perkawinannya kepada orang yang dianggap tahu tentang syarat dan rukum perkawinan dalam Agama, jadi mengenai adanya keraguan mengenai syarat dan rukun dalam perkawinan itu dianggap kurang tepat. Ketentuan perkawinan yang bisa diisbatkan adalah perkawinan yang dilakukan sebelum berlakunya Undang-Undang Nomor 1 Tahun 1974 namun pada kenyataannya perkara yang diajukan oleh pihak pemohon mengenai perkawinannya merupakan perkawinan yang terjadi setelah diberlakukan Undang-Undang tersebut, hal itu perlu menjadi acuan serta pertimbangan bagi para hakim dalam menerima perkara permohonan itsbat yang perkawinannya dilakukan setelah berlakunya aturan dalam pasal tersbut. Di antaranya adalah dalam hal pertimbangan sosial perkembangan hukum yang hidup dimasyarakat serta pertimbangan hakim dianggap tahu mengenai aturan hukum yang belum terdapat peraturan didalamnya termasuk istbat yang diajukan setelah 1974 ini.

Adanya halangan dalam perkawinan menurut Undang-Undang Perkawinan, halangan tersebut memiliki 2 pandangan: yang pertama dalah karena dalam halangan perkawinan tersebut mempunyai yang hubungan dalam Agamanya dilarang kawin, dan yang kedua karena mempunyai hubungan yang oleh dalam aturan lain yang diberlakukan memiliki unsur dilarang melakukan perkawinan. hal tersebut menggambarkan aturan dalam ketentuan pertama sudah jelas sedangkan aturan yang kedua belum jelas. Akan lebih luas lagi apabila dalam aturan pasal tersebut ditujukan untuk perkawinan yang dilakukan setelah berlakunya Undang-Undang Perkawinan maka dianggap kurang pas karena dapat memberikan lalu lintas yang lancar atau peluang bagi pelaku poligami untuk mengistbatkan perkawinannya. Lain halnya jika dalam pemberlakuan aturan tersebut dibatasi hanya untuk perkawinan yang terjadi sebelum diberlakukan Undang-Undang Nomor 1 Tahun 1974.

Dari segi hukum administrasi negara, sebagaimana yang diatur dalam Pasal 34 Undang-Undang Nomor 23 Tahun 2006 perkawinan yang sah menurut Undang-Undang wajib dilaporkan kepada pihak instansi yang berwenang selambatlambatnya adalah 60 hari sejak tanggal 
perkawinan dengan adanya penegakan Itsbat Nikah ini akan memberikan sebuah ketertiban administratif bagi penduduk yang melaksanakan perkawinan tersebut. Namun jika penduduk tersebut melakukan pelanggaran dengan tidak mencatatkan perkawinannya sebagai peristiwa hukum karena pencatatan perkawinan merupakan peristiwa penting yang memiliki akibat hukum maka pelanggar tersebut akan dikenakan hukuman administratif sebagaimana diatur dalam ketentuan Pasal 90 Nomor 23 Tahun 2006 angka 1, 2 dan 3.

Maka akan dikenakan sanksi administratif sebesar satu juta rupiah. Apabila menelisik pencatatan tersebut dalam Rancangan Undang-Undang Hukum Materiil Peradilan Agama Bidang Perkawinan Tahun 2007 dalam hal perkawinan yang sah dan sesuai hukum Perkawinan Islam, namun belum dicatatkan atau tidak dicatat maka pelakunya dapat dikenai pidana denda sebanyak enam juta rupiah maupun pidana penjara paling lama 6 bulan. Karena pelaku tersebut apabila perkawinan tidak dicatat atau tercatat dianggap sebagai seorang kriminal yang merupakan ketentuan sebagaimana diatur dalam Pasal 151 RUU-HM-PA-B Perkawinan Tahun 2007.

Dengan ditegakkannya Itsbat Nikah tersebut akan berimplikasi terhadap setiap perbuatan hukum yang lahir setelah perkawinan tersebut di antranya adalah perkawinan yang telah dilakukan menjadi legal dengan adanya penetepan dari pihak Pengadilan Agama Jepara serta memerintahkan untuk mencatatkan perkawinannya dengan membawa surat penetapan dari Pengadilan karena dengan adanya penetapan tersebut akan berimbas adanya penjaminan yang jelas atau konkret baik secara hukum serta memperoleh hak atas kepemilikan anak, serta anak yang lahir memiliki pengakuan hukum dari negara dan berhak mewarisi dari orang tuanya dalam hal ini adalah bapaknya juga setelah adanya penetapan itsbat nikah tersebut serta juga telah melaksanakan ketertiban hukum yang merupakan sebuah aturan administratif sebagaimana diatur dalam Undang-Undang Nomor 23 Tahun 2006 Tentang Adminitrasi Kependudukan, memperoleh kepastian terkait hak atas hukum serta kemudahan hukum selain hanya sebagai bukti otentik keabsahan perkawinan.

Berdasarkan hasil pemaparan pembahasan yang telah diuraikan diatas dapat disimpulkan dengan kata lain diadakannya Itsbat Nikah tersebut menegakkan terkait kepentingan terhadap pemenuhan aspek administrasi terhadap akibat hukum yang timbul dari perkawinan tersebut. Urgensinya mengenai pemenuhan syarat formil mengenai sahnya suatu perkawinan yang telah dilakukan baik bersifat prosedural maupun administratif karena jaminan dengan penegakkan Itsbat Nikah tersebut terlindunginya hak anak dan istri ketika terjadi perceraian serta melahirkan kepastian hukum terhadap status perkawinan tersebut yang menjadi tujuan mengapa permohonan Itsbat Nikah diajukan ke Pengadilan Agama Jepara serta pemenuhan hak atas harta benda dalam perkawinan dan juga status kewarisan anak serta tidak menutup kemungkinan sebagai payung hukum, kemudahan proses administrasi keperdataan lainnya yang lahir selama perkawinan. 


\section{KESIMPULAN}

Prosedur Itsbat Nikah di Pengadilan Agama Jepara, dalam Pelaksanaannya sama halnya seperti keperdataan lainnya yakni tahapan dimulai dengan pengajuan permohonan dari pihak, penerimaan perkara selanjutnya proses pemeriksaan perkara yang dilakukan dalam persidangan, pembacaan kesimpulan oleh majlis dan penetapan hakim terkait pengesahan perkawinan

Kendala dalam pelaksanaan Itsbat Nikah di Pengadilan Agama adalah datang dari pihak yang kurang dalam pemenuhan persyaratan dalam persidangan sehingga dalam proses sidang bisa berlangsung lama. Sedangkan kendala dalam masyarakat adalah kurang pengetahuan mengenai pentingnya pencatatan, akses lokasi pengadilan yang jauh dan kurang dalam pembiayaan serta sosialisasi dari pihak berwenang.

Implikasi yang diperoleh setelah adanya penetapan terkait pengesahan perkawinan adalah status perkawinan pemohon mempunyai kekuatan hukum tetap. Dimana kekuatan dari pengesahan tersebut akan berimbas kepada anak serta anak yang lahir dari perkawinan tersebut berhak mendapatkan pengakuan hukum sebagaimana ketentuan dalam UndangUndang. Adanya penetapan itsbat nikah ini menjadikan sebuah kemudahan dalam pengurusan administrasi keperdataan jaminan hak serta status perkawinan yang sah dan perlindungan hukum, waris mewarisi karena telah memiliki penetapan dan kekuatan hukum

\section{DAFTAR PUSTAKA}

Ahmad, S. (2016). Pelaksanaan Isbat Nikah
Di Pengadilan Agama Pandeglang. AHKAM: Jurnal Ilmu Syariah, 16(1).

Amir Mu'allim, Y. (2001). Konfigurasi Pemikiran Hukum Islam. Yogyakarta: UII Press Indonesia.

Djubaidah, N. (2012). Pencatatan Perkawinan dan Perkawinan Tidak Dicatat MenurutHukum Tertulis di Indonesian dan Hukum Islam. Jakarta: Sinar Grafika.

Faizah, B. (2014). Itsbat Nikah Dan Implikasinya Terhadap Status Perkawinan Menurut Peraturan Perundang-Undangan Indonesia. Ilmu Hukum Jambi, 4.

Keputusan Menteri Agama KMA Nomor 29 b Tahun 2003 tentang pencatatan Nikah.

Kharlie, A. T. (2013). Hukum Keluarga Indonesia. Jakarta: Sinar Grafika.

Mahmud, H. (2014). Yurisprudensi Isbat Nikah Dalam Pasal 7 Kompilasi Hukum Islam. Religi Jurnal Studi Islam, 5(1).

Mukhtaruddin, B. (2013). Legalisasi Nikah Sirri Melalui Isbat Nikah Menurut Kompilasi Hukum Islam. Diskursus Islam, 1(2).

Ramulyo, I. (2006). Hukum Perkawinan, Hukum Kewarisan, Hukum Acara Peradilan Agama dan Zakat Menurut Hukum Islam. Jakarta: Sinar Grafika.

Soekanto, S. (2015). Pengantar Penelitian Hukum. Jakarta: UI Press.

Undang-undang RI Nomor 1-2 Tahun 1974 Tentang Perkawinan.

Undang-Undang Nomor 3 Tahun 2006 tentang Perubahan atas Undang- 
Undang Nomor 7 Tahun 1989 Peraturan Menteri Agama Nomor 19 tentang Peradilan Agama.

Peraturan Pemerintah Nomor9 Tahun 1975 tentang Pelaksanaan UndangUndang Nomor 1 Tahun 1974 Tentang Perkawinan Tahun 2018 Tentang Pencatatan Perkawinan

Yakin, M. K. (2015). Ratio Decidendi Penetapan Pengesahan (Itsbat) Nikah DiPengadilan Agama. Yuridika Fakultas Hukum Universitas Airlangga, 30. 